\title{
Evaluation of the genotoxicity induced by the fungicide fenarimol in mammalian and plant cells by use of the single-cell gel electrophoresis assay
}

\author{
P. Poli ${ }^{\text {a,b,* }}$, M.A. de Mello ${ }^{\text {, A. Auschini }}{ }^{\text {a }}$, V.L.S.S. de Castro ${ }^{\mathrm{c}}$, \\ F.M. Restivo ${ }^{a}$, C. Rossi ${ }^{\text {a }}$, T.M.A.D. Zucchi ${ }^{b}$ \\ ${ }^{a}$ Dipartimento di Genetica Antropologia Evoluzione, Università degli Studi di Parma, Parco Area delle Scienze11/a, 43100 Parma, Italy \\ ${ }^{\mathrm{b}}$ Dep.to de Parasitologia, Instituto de Ciências Biomédicas, USP, Av. Prof. Lineu Prestes, 1374, \\ Cidade Universitária, 05508-900 São Paulo, SP, Brazil \\ ${ }^{\mathrm{c}}$ Embrapa Meio Ambiente, Laboratório de Ecotoxicologia, Rodovia SP 340, km 127.5, 13820-000 Jaguariúna, SP, Brazil
}

Received 23 December 2002; received in revised form 18 June 2003; accepted 27 June 2003

\begin{abstract}
Fenarimol, a systemic pyrimidine carbinol fungicide, is considered to be not genotoxic or weakly genotoxic, although the available toxicological data are controversial and incomplete. Our results obtained in vitro with leukocytes of two different rodent species (rat and mouse) show that fenarimol affects DNA, as detected by the single-cell gel electrophoresis (SCGE, Comet) assay. This fungicide is able to induce DNA damage in a dose-related manner, with significant effectiveness at $36 \mathrm{nM}$, but without significant interspecies differences. Simultaneous exposure of rat leukocytes to fenarimol (36-290 nM) and a model genotoxic compound $(50 \mu \mathrm{g} / \mathrm{ml}$ bleomycin) produced a supra-additive cytotoxic and genotoxic effect. This supports previous findings suggesting possible co-toxic, co-mutagenic, cancer-promoting and co-carcinogenic potential of fenarimol, and modification of the effects of other xenobiotics found to be influenced by this agrotoxic chemical, with consequent different toxicological events. The potential for DNA strand breaks to act as a biomarker of genetic toxicity in plants in vivo was also considered, in view of the fact that higher plants represent reliable sensors in an ecosystem. Significant DNA breakage was observed in the nuclei of Impatiens balsamina leaves after in vivo treatment with fenarimol $(145 \mathrm{nM}, 1 \mathrm{~h})$. More than $50 \%$ of the cells showed such DNA damage.
\end{abstract}

(C) 2003 Elsevier B.V. All rights reserved.

Keywords: Fenarimol; Comet assay; DNA damage; Agrotoxic; Biomarkers

\section{Introduction}

Short-term tests may be used to predict carcinogenesis when their endpoints measure the genotoxic potential of chemicals, i.e. their capacity of initiating

\footnotetext{
* Corresponding author. Tel.: +39-0521-905608; fax: +39-0521-905604.

E-mail address: mutgen@unipr.it (P. Poli).
}

multistep carcinogenesis. Furthermore, biological measures (biomarkers) are developed to provide information on the effects of exposure and/or susceptibility to a variety of environmental contaminants. These biomarkers have a range of practical applications including, among others, evaluation of toxicity mechanisms and endpoints [1]. Many aspects of doseresponse assessment and extrapolation methodology can be improved by incorporating biomarker data [2]. 
The effects of exposure to pesticides need to be determined because of the potential impact they have on both the environment and the population. The study of the mechanisms involved is essential for the development of approaches that can be used for public health risk assessment and decision-making with regard to safe usage [3].

Pesticides are substances for which the toxicity, at both the genetic and the metabolic level, has not been adequately described. Preliminary results on a broad series of compounds belonging to different biological classes (herbicides, insecticides, fungicides) seem to indicate that pesticides are toxic yet poor initiating agents, as shown by negative or weakly positive results on different genetic endpoints [4]. Immunochemical and biochemical studies seem to indicate the co-carcinogenic and promoting potential of these chemicals.

Fenarimol is a widely used organic fungicide possessing both preventive and curative activity with local systemic action for the effective control of scab of apples, powdery mildew of peas, cherries, grapes, etc. Results concerning the effects of this compound are still not completely clear and, in some cases, contradictory and thus it may exert carcinogenic effects in vivo. The addition of the S9 fraction as an exogenous metabolic system leads to a decrease in cytotoxic effects and to a reduction of the cell transformation rate [5]. Fenarimol has been shown to selectively induce cytochrome $\mathrm{P} 450-2 \mathrm{~B} 1$ isoforms in different organs of treated mice [6]. Selective biochemical markers have indicated a possible co-toxic, co-mutagenic, co-carcinogenic and promoting potential of this fungicide [7,8]. Di Ilio et al. [9] have shown the electrophilic nature of the fungicide and suggested its possible reactivity with DNA. Vicia $f a b a$ roots, treated with different concentrations of fungicide, showed that fenarimol is able to produce numerical but not structural chromosomal aberrations [10]. When tested in vivo on rat, fenarimol is capable of inducing DNA damage in hepatocytes with a significant increase of DNA unwinding [11]. However, in vivo this fungicide does not induce any significant dose-related increase in erythrocytes from mouse bone marrow [8].

Major endpoints of short-term genotoxicity assays include DNA damage, point mutations, chromosomal aberrations, etc. [12]. The sensitivity of the single-cell gel electrophoresis (SCGE) or Comet assay allows rapid prediction of genotoxic potential of compounds and has been shown to be useful for in vivo and in vitro biomonitoring of environmental pollutants [13-17].

The use of plant material appears to be particularly practical for the assessment of environmental health risks. Higher plants, sensitive to soil, water and air pollutants, have been widely used for the biomonitoring of DNA damage induced by genotoxic agents: they can metabolise promutagens and be useful in detecting genotoxic compounds in complex mixtures. The measurement of DNA damage by use of the SCGE assay in the nuclei of higher plants has been applied to various tissues: seeds [18], roots of $V$. faba [19-24] and Allium cepa [25], and leaves of Nicotiana tabacum [21,23,26,27]. Impatiens balsamina and different cultivars of $N$. tabacum were used in our laboratory [28-30].

The main goals of this study are:

- To measure the possible interactions of fenarimol with DNA by using the Comet assay [31,32].

- To evaluate the specific sensitivity in vitro against the fungicide in the leukocytes of two different rodent species (rat and mouse).

- To detect a possible co-toxic/co-genotoxic potential of fenarimol.

- To establish the method and doses to investigate whether the wild plant species I. balsamina, present in tropical regions, is sensitive to fenarimol. Plants such as I. balsamina could become a sensitive biomarker for the biomonitoring of environmental pollution, which is particularly appealing in developing countries like Brazil, where the improvement of agricultural production involves a simultaneous use of pesticides.

- To compare the performance and sensitivity of different methods for Comet analysis [33] and to choose the more useful screening for in situ monitoring.

\section{Material and methods}

\subsection{Chemicals}

Reagents for electrophoresis, normal melting point agarose (NMA) and low melting point agarose (LMA), 
plant growth medium (MS; cat. \#M5519), dimethyl sulfoxide (DMSO), ethidium bromide (EtBr), fluorescine diacetate (FDA), and general laboratory chemicals were from Sigma. Bleomycin (Bleomicina ${ }^{\circledR}$ ) was obtained from Rhône-Poulenc Rorer (Milan, Italy) and fenarimol, i.e. $\alpha$-(2-chlorophenyl)- $\alpha$-(4-chlorophenyl)5-pyrimidinemethanol (CAS 60168-88-9; PM: 331.20) was obtained from Dow AgroSciences (Indianapolis, USA) as the commercial product Rubigan ${ }^{\circledR}$ containing $120 \mathrm{mg} / \mathrm{ml}$ of active principle.

\subsection{Mammalian cells}

\subsubsection{Animal species and strains}

Parasite-free male Wistar rats (8-9 weeks old) and $\mathrm{Balb} / \mathrm{C}$ mice (6 weeks old) from our own colony (Embrapa Meio Ambiente, SP, Brazil) were used for experimentation. The animals were housed in polypropylene cages at a controlled temperature $\left(22 \pm 2^{\circ} \mathrm{C}\right)$, relative humidity of $70 \%, 12 \mathrm{~h}: 12 \mathrm{~h}$ day/night cycle and fed with standard rodent chow (Purina) and tap water ad libitum. Housing and treatment of animals were in accordance with national and institutional guidelines.

The animals were sacrificed (common ether chamber) just before the collection of heparin-anticoagulated blood and the treatment of isolated leukocytes.

\subsubsection{Cell treatment}

Whole blood was centrifuged, maintained for $10 \mathrm{~min}$ in an erylyse solution for leukocyte isolation $\left(155 \mathrm{mM} \mathrm{NH} \mathrm{NH}_{4} \mathrm{Cl}, 5 \mathrm{mM} \mathrm{KHCO}_{3}, 0.005 \mathrm{mM}\right.$ $\mathrm{Na}_{2}$ EDTA, pH 7.4) at $37^{\circ} \mathrm{C}$, washed with PBS and resuspended $\left(\sim 10^{6}\right.$ cell $\left./ \mathrm{ml}\right)$ in phosphate buffer saline (PBS). Medium containing cells and appropriate volumes of Rubigan ${ }^{\circledR}$ to obtain different concentrations of fenarimol (five doses, 0, 12, 24, 48, and $96 \mathrm{ng} / \mathrm{ml}$, corresponding to $0,36,72,145$, and $290 \mathrm{nM}$, respectively) or positive control $(50 \mu \mathrm{g} / \mathrm{ml}$ bleomycin $)$ were added to an Eppendorf tube. Fenarimol concentrations are selected after a cytotoxicity screening: $360 \mathrm{nM}$ fenarimol induces about $50 \%$ cell mortality. Treatments were for $1 \mathrm{~h}$ at $37^{\circ} \mathrm{C}$.

Rat cells were also treated simultaneously with a model genotoxic compound $(50 \mu \mathrm{g} / \mathrm{ml}$ bleomycin $)$ and various doses (range: $36-290 \mathrm{nM}$ ) of fenarimol to evaluate possible synergic/antagonistic effects. Bleomycin, a radiomimetic antitumor drug, was se- lected as a free radical-based DNA damaging agent that induces a mixture of strand breaks and abasic sites $[34,35]$.

Cell viability was checked by the FDA/EtBr assay [36]. The Comet assay was performed only with cell viability $\geq 70 \%$.

The SCGE assay was performed basically according to Singh et al. [31]. The cells $\left(\sim 2 \times 10^{5}\right)$, mixed with $85 \mu \mathrm{l}$ of $0.7 \%$ low melting agarose, were placed on degreased slides previously dipped in $1 \%$ normal melting agarose. Then $85 \mu \mathrm{l}$ of LMA were added as the top layer and the cells lysed at $4{ }^{\circ} \mathrm{C}$ in the dark overnight $(2.5 \mathrm{M} \mathrm{NaCl}, 10 \mathrm{mM} \mathrm{Na} 2$ EDTA, $10 \mathrm{mM}$ Tris-HCl, $1 \%$ Triton $\mathrm{X}-100$ and $10 \%$ DMSO, pH 10). The DNA was allowed to unwind for $20 \mathrm{~min}$ in an electrophoretic alkaline buffer $(1 \mathrm{mM} \mathrm{Na} 2$ EDTA, $300 \mathrm{mM} \mathrm{NaOH}, \mathrm{pH} \geq 13$ ) and subjected to electrophoresis for $20 \mathrm{~min}$ at $0.78 \mathrm{~V} \mathrm{~cm}^{-1}$ and $300 \mathrm{~mA}$. The slides were then washed in a neutralisation buffer (0.4 M Tris- $\mathrm{HCl}, \mathrm{pH} 7.5)$ to remove alkali and detergent. Immediately before examination, the DNA was stained with $70 \mu \mathrm{l}$ ethidium bromide $(2 \mu \mathrm{g} / \mathrm{ml})$. The samples were examined at $400 \times$ magnification under a Leika DMLB fluorescent microscope equipped with an excitation filter BP $515-560 \mathrm{~nm}$ and a barrier filter LP $580 \mathrm{~nm}$.

The samples were coded and evaluated blind (50 cells per each of two replicate slides per data point). All the tests were performed at least three times.

\subsection{Plant cells}

\subsubsection{Plant seeds}

I. balsamina, commonly commercialised seeds.

\subsubsection{Plant growth conditions}

Seed germination was performed in plastic pots $(\varnothing=10 \mathrm{~cm})$ containing vermiculite and irrigated with tap water. After germination, the seedlings were transferred in new plastic pots (three seedlings per pot). During germination and growth, the plantlets were irrigated with diluted (1/10) MS medium. Intact plantlets (about 45 days old, after germination) were used for the experiments.

\subsubsection{Plant treatments}

The plantlets were extracted from the pots and vermiculite carefully removed from the roots by several 
tap water washings. The roots of whole plantlets were dipped in Eppendorf tubes containing $1 \mathrm{ml}$ of the appropriate concentration of fenarimol (or $\mathrm{H}_{2} \mathrm{O}_{2}$ as positive control) in distilled water and incubated for $1 \mathrm{~h}$ in daylight conditions.

\subsubsection{Single-cell gel electrophoresis}

The SCGE assay was performed as previously described [30]. Leaf samples were cut and various cut surfaces were dipped directly into a drop of LMA ( $0.5 \%$ in PBS) resting on the top of the first agarose layer. The slides were placed on a warm surface $\left(37^{\circ} \mathrm{C}\right)$ during this stage. Finally, LMA was added as the top layer. The procedure resulted in a uniform distribution of nuclei in the agarose layer.

The DNA was allowed to unwind for $15 \mathrm{~min}$ in an electrophoretic alkaline buffer $(1 \mathrm{mM} \mathrm{Na} 2$ EDTA, $300 \mathrm{mM} \mathrm{NaOH}, \mathrm{pH} \geq 13)$ and subjected to electrophoresis in the same buffer for $10 \mathrm{~min}$ at $0.66 \mathrm{~V} \mathrm{~cm}^{-1}$ and $230 \mathrm{~mA}$. These conditions are previous reported [30] as optimal for I. balsamina cells in order to get minimum DNA migration in the control group and, at the same time, maximum sensitivity for the treated sample.

Subsequent steps were performed as in the SCGE assay for mammalian cells.

\subsection{DNA damage evaluation}

In the absence of an automatic system, two different methods for Comet analysis, both reported in Tice et al. [37], were used.

The evaluation of genotoxic effect was first obtained as a visual perception of DNA damage. A number of 100 randomly selected cells per sample were visually scored according to tail intensity, determining the frequency of round nuclei, nuclei with short tails, nuclei with medium long tails, and nuclei with long tails and categorising nuclei as undamaged (i.e. no migration), short migration, medium migration and long migration. Thus, the damage score for each sample can range from 100 (completely round nuclei: 100 cells $\times 1$ ) to 400 (maximally damaged: 100 cells $\times 4$ ). Cells with complete DNA migration were defined as 'ghost cells' or 'hedgehog' and were reported as percentage on 200 randomly selected cells. When present, the hedgehog cells were reported but not included in statistical treatment of the genotoxicity data because the origin of the damage is unclear, i.e. necrosis or/and apoptosis [38].

A measure (arbitrary units) of migration length and diameter of the Comet head (measured perpendicularly to the direction of the electric field) was also performed on the same randomly selected cells previously scored (100 cells per sample). Each Comet

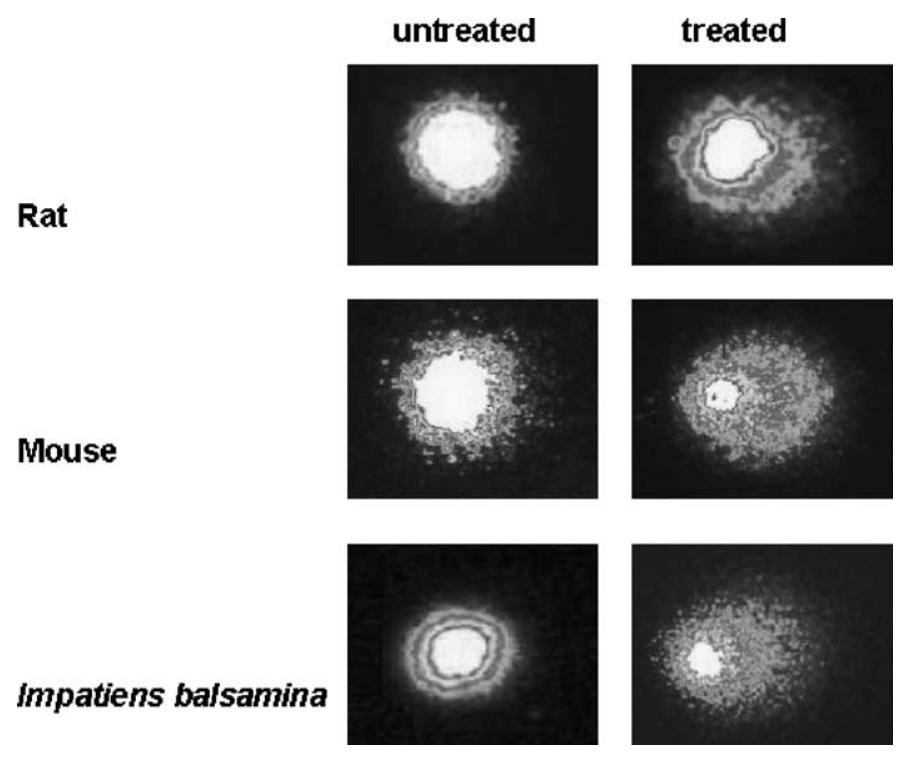

Fig. 1. Comet images representative of treated and untreated rat and mouse cells and plant cells. 
image was saved (digital camera Kodak DC 120) and measured by using a ruler. The length/diameter ratio (LDR) was then calculated. Comet images representative of treated and untreated rat and mouse leukocytes and plant cells are reported in Fig. 1 .

\subsection{Statistical analysis}

A SPSS 11 statistical package was applied both to score and to collected LDR data from at least three independent experiments. Statistical differences between controls and treated samples were first determined with non-parametric Wilcoxon rank-sum test for each experiment [39]. The Comet parameters, i.e. LDR (mean, median, etc.) and mean visual score, were calculated for each treatment group. The mean values from the repeated experiments were used in a one-way analysis of variance test. If a significant $F$-value of $P<0.05$ was obtained, a Dunnett's $C$ multiple comparison analysis (equal variances not assumed) was conducted.

\section{Results}

\subsection{Effects of fenarimol on leukocytes from mouse and rat in the Comet assay}

The effects of the fungicide were tested on rodent leukocytes in the concentration range of $0-96 \mathrm{ng} / \mathrm{ml}$. Viability, both for mouse and rat cells, was always $\geq 70 \%$ immediately after treatment for all the doses, as recommended for Comet assay by the International Workshop on Genotoxicity Test Procedures [37].

In mouse leukocytes, an induction of DNA breaks (mostly single-strand breaks) is observed after fenarimol treatment. An increase of visual score values and frequencies of damaged cell classes is evident at increasing fungicide doses (Table 1A). The first dose of fungicide $(36 \mathrm{nM})$ gives significantly different effects $(P<0.05)$ with respect to the control (dose $0)$. LDR values confirm the data obtained with the visual score. The number of hedgehog cells is not affected by the treatment whereas cell survival is dosedependent.

To expand the data obtained on mouse cells to other mammalian cells, we also performed the same treatment in vitro on fresh rat leukocytes. The data confirmed the findings on mouse cells, and a dose-response DNA damage induction was found (Table 1B) even if a different initial score for DNA breakage in untreated rat cells as compared to mouse cells is evident: most of the cells (about 80\%) in the negative control group of rat leukocytes are undamaged, i.e. class 1 , whereas, for untreated mouse leukocytes, many of the comets are in the classes 2 and 3 (about 40 and 30\%, respectively). Differing endogenous DNA damage levels may reflect the diversity between biological systems, a fact also borne out by the differences seen between endogenous DNA damage levels in canine and feline leukocytes [40]. We can hypothesise that a different metabolism, with a consequent different production of endogenous free radicals, in the two species might affect the cells. In rat cells, the mean damage classes have a significant linear correlation with doses $\left(R^{2}=0.974\right)$. Statistical analysis of visual score and LDR data (Table 1B) shows significant differences $(P<0.001)$ among all the treated samples and the control (dose 0). DNA breakage is linearly correlated with dose whichever parameters of the Comet assay are considered $\left(R^{2}>\right.$ 0.95 in all cases). A significant cytotoxicity, but lower than in mouse leukocytes, is observed at increasing fenarimol concentrations whereas this relationship is not seen for the "hedgehog" cells.

Fenarimol is known to induce some cytochrome P450 [6]. Furthermore, the binding of fenarimol by glutathione transferases has been shown [9]. Since the rate of metabolism and the stereo-specificity of metabolism are governed by the biochemical conditions of the cells, and especially by the content of specific drug metabolising enzymes (for example, the types and amount of P450s and glutathione transferases available), fenarimol might drastically alter the activity of other xenobiotics and their toxicological consequences. For these reasons, the cytotoxic and genotoxic effects of fenarimol were evaluated in vitro on rat leukocytes together with those of bleomycin, the effectiveness of which has already been shown in our previous studies [41].

On rat cells treated simultaneously with the two compounds (Table 1C), both the cytotoxicity and the genotoxicity increased with respect to the effects induced by fenarimol alone. The data on rat leukocytes show an overall effect higher than the sum (theoretical values) of the effects induced by each 
Table 1

Rodent leukocytes: genotoxic and cytotoxic effects induced by fenarimol in mouse (A) and rat leukocytes without (B) or with $(\mathrm{C}) 50 \mu \mathrm{g} / \mathrm{ml}$ bleomycin

\begin{tabular}{|c|c|c|c|c|}
\hline Dose (nM) & Mean LDR & Visual score & "Hedgehog" (\%) & Cell survival $(\%)$ \\
\hline \multicolumn{5}{|l|}{ A } \\
\hline 0 & $1.73 \pm 0.12$ & $207 \pm 15$ & $1.17 \pm 0.29$ & $97.6 \pm 1.2$ \\
\hline 36 & $1.92 \pm 0.08$ & $242 \pm 5^{*}$ & $1.00 \pm 0.87$ & $94.6 \pm 1.4^{*}$ \\
\hline 72 & $2.23 \pm 0.12^{* *}$ & $284 \pm 6^{* * *}$ & $1.33 \pm 0.29$ & $90.3 \pm 1.7^{* *}$ \\
\hline 145 & $2.72 \pm 0.23^{* * *}$ & $300 \pm 7^{* * *}$ & $1.17 \pm 0.76$ & $86.8 \pm 1.9^{* * *}$ \\
\hline 290 & $3.02 \pm 0.32^{* * *}$ & $319 \pm 2^{* * *}$ & $1.00 \pm 0.50$ & $83.2 \pm 2.1^{* * *}$ \\
\hline 360 & - & - & - & $56.3 \pm 3.2^{* * *}$ \\
\hline Bleomycin $(50 \mu \mathrm{g} / \mathrm{ml})$ & $3.13 \pm 0.27^{* * *}$ & $290 \pm 5^{* * *}$ & $0.83 \pm 0.29$ & $96.2 \pm 1.3$ \\
\hline \multicolumn{5}{|c|}{ 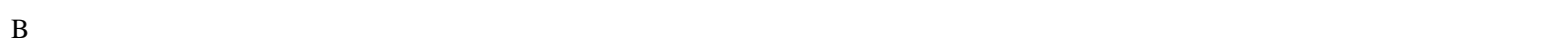 } \\
\hline 0 & $1.15 \pm 0.04$ & $123 \pm 3$ & $0.33 \pm 0.29$ & $96.7 \pm 0.5$ \\
\hline 36 & $1.49 \pm 0.05^{* * *}$ & $176 \pm 6^{* * *}$ & $0.67 \pm 0.29$ & $95.6 \pm 1.4$ \\
\hline 72 & $1.62 \pm 0.08^{* * *}$ & $203 \pm 3^{* * *}$ & $0.17 \pm 0.29$ & $93.4 \pm 1.0^{* *}$ \\
\hline 145 & $1.97 \pm 0.14^{* * *}$ & $241 \pm 3^{* * *}$ & $0.67 \pm 0.29$ & $90.8 \pm 1.5^{* *}$ \\
\hline 290 & $2.53 \pm 0.17^{* * *}$ & $271 \pm 4^{* * *}$ & $0.83 \pm 0.58$ & $90.0 \pm 1.8^{* *}$ \\
\hline \multicolumn{5}{|l|}{$\mathrm{C}$} \\
\hline 0 & $2.54 \pm 0.13^{* * *}$ & $236 \pm 6^{* * *}$ & $1.00 \pm 0.50$ & $95.4 \pm 1.0$ \\
\hline 36 & $2.99 \pm 0.25^{* * *}$ & $247 \pm 5^{* * *}$ & $0.83 \pm 0.29$ & $91.1 \pm 0.4^{* * *}$ \\
\hline 72 & $4.63 \pm 0.24^{* * *}$ & $306 \pm 3^{* * *}$ & $1.17 \pm 0.29$ & $85.2 \pm 1.1^{* * *}$ \\
\hline 145 & $7.03 \pm 0.41^{* * *}$ & $323 \pm 4^{* * *}$ & $1.00 \pm 0.50$ & $80.7 \pm 2.6^{* * *}$ \\
\hline 290 & $9.18 \pm 0.25^{* * *}$ & $349 \pm 3^{* * *}$ & $1.17 \pm 0.29$ & $77.3 \pm 0.8^{* * *}$ \\
\hline
\end{tabular}

The length/diameter ratio (LDR) values, visual score, hedgehog cells and cell survival are reported. Mean \pm S.D. from three independent experiments.

${ }^{*} P<0.05$, with respect to dose 0 without bleomycin (Dunnett's $C$-test).

** $P<0.01$, with respect to dose 0 without bleomycin (Dunnett's $C$-test).

*** $P<0.001$, with respect to dose 0 without bleomycin (Dunnett's $C$-test).

single compound separately (i.e. the sum of effect induced by $50 \mu \mathrm{g} / \mathrm{ml}$ bleomycin and by different doses of fungicide): the co-genotoxic potential of fenarimol appears to be dose-dependent and higher than its own genotoxic potential as shown in Fig. 2A, which reports the difference of DNA fragmentation between the values obtained with the two xenobiotics together and the theoretical values. A supra-additive effect in terms of cytotoxicity was also observed (Fig. 2B).

Table 2

Impatiens balsamina: genotoxic and cytotoxic effects induced by fenarimol $(145 \mathrm{nM})$

\begin{tabular}{llll}
\hline & Control (average \pm S.D.) & $\mathrm{H}_{2} \mathrm{O}_{2}$ (average \pm S.D.) & Fenarimol (average \pm S.D.) \\
\hline Mean LDR & $1.08 \pm 0.03$ & $1.39 \pm 0.07^{* * *}$ & $1.45 \pm 0.07^{* * *}$ \\
LDR 95th percentiles & $1.35 \pm 0.03$ & $2.33 \pm 0.09^{* * *}$ & $2.41 \pm 0.08^{* * *}$ \\
LDR > SRGL 95th (cell no.) & 5 & $56.0 \pm 10.7^{* * *}$ & $60.5 \pm 13.4^{* * *}$ \\
Visual score & $181 \pm 18$ & $268 \pm 7^{* * *}$ & $298 \pm 6^{* * *}$ \\
"Hedgehog" (\%) & $0.83 \pm 0.29$ & $1.00 \pm 0.50$ & $1.17 \pm 0.29$ \\
Cell survival (\%) & $97.7 \pm 2.5$ & $97.4 \pm 1.5$ & $96.0 \pm 2.6$
\end{tabular}

Cytotoxicity and Comet parameters (length/diameter ratio (LDR) and visual score values) are reported. Average mean and percentile of LDR and the number of cells exhibiting values greater than the 95\% confidence limits (SRGL: superior reference group limit) for the distribution of the control data (considered as damaged cells) are reported. Positive control: $100 \mathrm{mM}$ hydrogen peroxide. Data of three independent experiments.

*** $P<0.001$, with respect to the control (Dunnett's $C$-test). 
(A) Genotoxicity

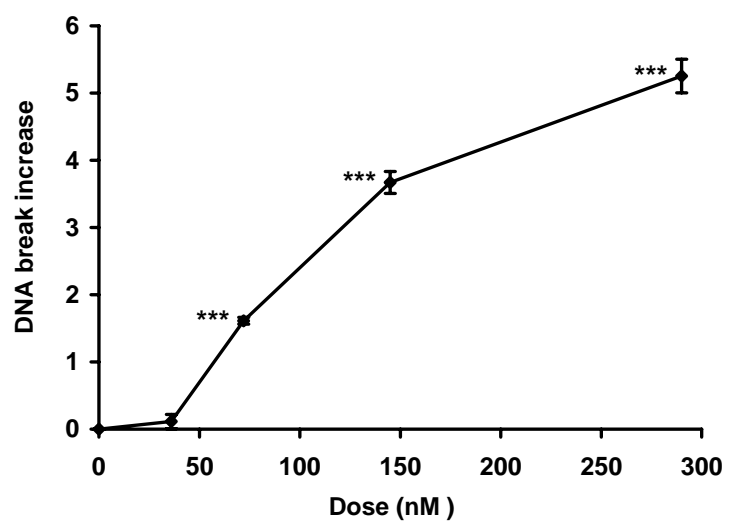

(B) Cytotoxicity

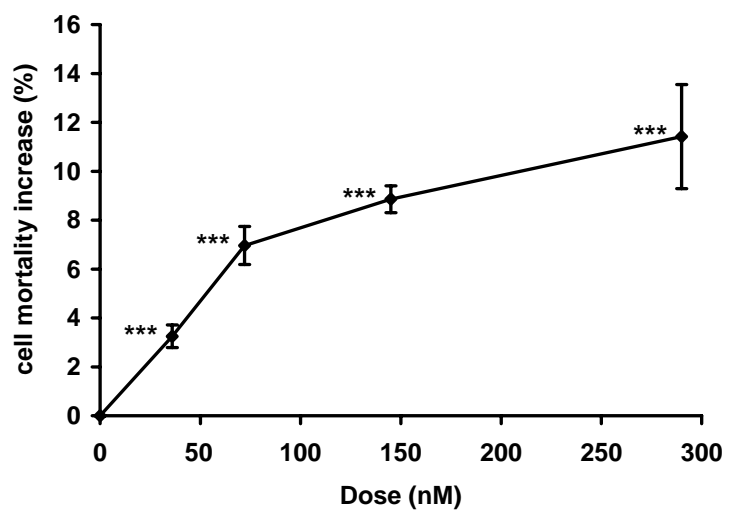

Fig. 2. Supra-additive genotoxic (LDR, panel A), and cytotoxic (panel B) effects in rat leukocytes treated with $50 \mu \mathrm{g} / \mathrm{ml}$ bleomycin in the presence of increasing concentrations of fenarimol. The results are reported as differences between the values obtained with the simultaneous administration of the two xenobiotics and the theoretical values, i.e. the sum of the effects induced by each single compound separately. Values are mean \pm S.D. of three independent experiments. (***) $P<0.001$ (Dunnett's $C$-test).

\subsection{In vivo effects of fenarimol on the plant Impatiens balsamina in the Comet assay}

A significant increase of DNA breakage is also detected by the Comet assay in vivo in the plant I. balsamina after $48 \mathrm{ng} / \mathrm{ml}$ fenarimol treatment (at least three independent experiments). The effects induced by fenarimol give results comparable to those induced by $100 \mathrm{mM} \mathrm{H}_{2} \mathrm{O}_{2}$ used as positive control [30], considering both visual score and LDR (Table 2). For LDR, the effects could be better described by frequency distribution parameters other than the mean. Therefore, LDR median and percentile and the number of cells which exhibit values greater than the $95 \%$ confidence limits (SRGL), for the distribution of the control data, are reported. All parameters used gave a good account of the effect (treated versus control: $P<0.001$ ), although the low values (related to the method of measure) of the mean do not allow the differences to be immediately perceived. On the other hand, the percentiles increase more than 1.5 times. Finally, the parameter 'number of cells with LDR > SRGL' appears particularly appealing because more than $50 \%$ of cells are scored as damaged (i.e. an increase of effect more than 10 times).

\section{Discussion and conclusions}

Pesticides are chemicals used to control agricultural pests, and their widespread application involves the assessment of their potential hazardous effects. Nearly $60 \%$ of oncogenic risk estimated to be due to pesticide exposure has been assigned to fungicides [42].

Fenarimol, a widely used fungicide, is considered to be not genotoxic or weakly genotoxic although the available toxicological data are controversial and incomplete. Our results on the leukocytes of two different rodent species (rat and mouse) in vitro indicate the induction of DNA breakage by fenarimol as shown by the Comet assay. This fungicide is able to induce DNA damage in a dose-related manner, with significant effectiveness already at $36 \mathrm{nM}$. No differences were seen between the effects on rat and mouse leukocytes.

The simultaneous administration of fenarimol and a model genotoxic compound $(50 \mu \mathrm{g} / \mathrm{ml}$ bleomycin $)$ on rat leukocytes induces a supra-additive effect, i.e. higher than the sum of the effects of each compound separately, in terms of cytotoxicity and genotoxicity. These results are in line with previous findings suggesting a co-toxic, co-mutagenic, cancer-promoting and co-carcinogenic potential of fenarimol $[7,8]$, as well as a modifying action on the effects of other xenobiotics such as bleomycin.

Ecological indicators can be used to assess the condition of the environment, to provide an early warning signal of changes in the environment, or to diagnose 
the cause of an environmental problem. In this context, higher plants represent a sensor able to follow the evolution of the genotoxic impact in an ecosystem.

In this research, the potential for DNA damage, as measured by the Comet assay, to act as a biomarker of genetic toxicity in plants in vivo was considered. A significant increase of DNA migration was observed on the nuclei obtained from I. balsamina leaves after the roots of the whole plantlets were dipped into fenarimol solution $(145 \mathrm{nM})$ for $1 \mathrm{~h}$. As a result, more than $50 \%$ of the cells were damaged by the treatment with the fungicide.

A secondary aim of this study was to explore and compare the performance and sensitivity of two different methods [37] for quantifying DNA migration in the Comet assay, and consequently to suggest the more useful screening for in situ monitoring. Therefore, in the absence of an automated system, the evaluation of the genotoxic effect was performed both as a visual perception of DNA damage and as the ratio between migration length and diameter (LDR) of the Comet head when measured (arbitrary units) on every image of a previously scored comet. The genotoxic action of fenarimol was confirmed by using the two measure types. On the other hand, the two methods showed a different sensitivity in relation to damage amount: the visual score is obviously less time-consuming and its sensitivity at low levels of exposure is better than LDR under the present protocols (Fig. 3). This was also reported by Kobayashi et al. [33] in comparison with computerised image analysis.

In conclusion, fenarimol is shown to be able to induce DNA damage both on in vitro mammalian and in vivo plant cells. Our results are in agreement with previous data on fenarimol-induced genotoxicity [9-11]. Although we cannot directly compare DNA migration in mammalian and plant cells due to different DNA amount and nuclei size, the comparison of the number of damaged cells (i.e. cells with LDR > SRGL 95th) shows higher sensitivity in I. balsamina $(60.5 \pm 13.4 \%$ of cell resulted damaged at $48 \mathrm{ng} / \mathrm{ml})$ than in rat and mouse $(43.3 \pm 7.2 \%$ and $39 \pm 8.5 \%$, respectively).

The results on the mammalian cells confirm the sensitivity of the Comet assay not only in detecting the effects of single compounds but also in evaluating the possible interactions among various xenobiotics.

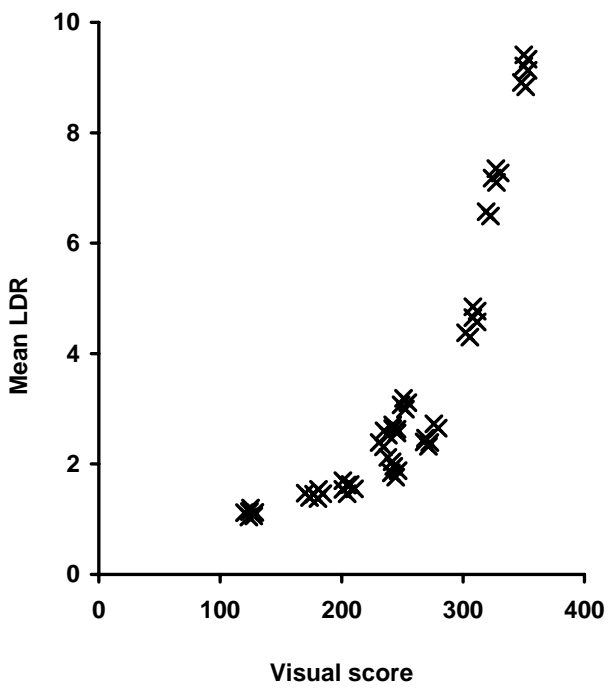

Fig. 3. Comparison of two methods for measuring DNA damage in the Comet assay (rat leukocytes). The relationship between the visual score and mean LDR values (as defined in Section 2) of each sample is reported.

This supports previous findings suggesting a possible co-toxic, co-mutagenic, cancer-promoting and co-carcinogenic potential of fenarimol [6-8]. Furthermore, our findings in vivo on I. balsamina suggest that the application of the test to plant tissues could be useful in the estimation of the bioavailability and genotoxic damage of pollutants to higher plants. As shown in our previous studies [28], the Comet assay could be applied to all plant tissues (roots and epigean parts). Furthermore, the method was shown to be able to detect both genotoxicants present in the soil and air pollutants, including volatile compounds $[19,20,26,30]$. Thus, the assay could be incorporated into in situ plant monitoring of environmental exposure to pesticides. The measure of DNA damage could easily assess the biological effectiveness of environmental genotoxic pollutants, provide an early warning signal of changes in the environment, and diagnose the cause of an environmental problem.

Furthermore, the ability to detect DNA damage by simple visual score (and the high sensitivity of this method at low exposure levels, as normally found in environmental samples) could permit the use of the Comet assay also in the absence of expensive image-analysis techniques for ambient monitoring. 


\section{Acknowledgements}

This work was supported by grants from FAPESP, Brazil. We would like to thank Dr. Gillian Mansfield (Director of the Language Centre, University of Parma) for the English revision of the manuscript.

\section{References}

[1] R.A. Ponce, S.M. Bartell, T.J. Kavanagh, J.S. Woods, W.C. Griffith, R.C. Lee, T.K. Takaro, E.M. Faustman, Uncertainty analysis methods for comparing predictive models and biomarkers: a case study of dietary methyl mercury exposure, Regul. Toxicol. Pharmacol. 28 (1998) 96-105.

[2] A.P. Decaprio, Biomarkers: coming of age for environmental health and risk assessment, Environ. Sci. Technol. 31 (1997) 1837-1848.

[3] T.D. Bucheli, K. Font, Induction of cytochrome P-450 as a biomarker for environmental contamination in aquatic ecosystems, Crit. Rev. Environ. Sci. Technol. 25 (1995) 201268.

[4] G. Cantelli-Forti, M. Paolini, P. Hrelia, Multiple end point procedure to evaluate risk from pesticides, Environ. Health Perspect. 101 (1993) 15-20.

[5] P. Perocco, A. Colacci, S. Grilli, In vitro cell transformation induced by the pesticide fenarimol, Res. Commun. Chem. Pathol. Pharmacol. 80 (1993) 345-356.

[6] P. Hrelia, F. Maffei, F. Vigagni, C. Fimognari, P. Flori, R. Stanzani, G. Cantelli Forti, Interactive effects between trichloroethylene and pesticides at metabolic and genetic level in mice, Environ. Health Perspect. 102 (1994) 31-34.

[7] M. Paolini, R. Mesirca, L. Pozzetti, A. Sapone, G. Cantelli-Forti, Molecular non-genetic biomarkers related to fenarimol cocarcinogenesis: organ- and sex-specific CYP induction in rat, Cancer Lett. 101 (1996a) 171-178.

[8] M. Paolini, R. Mesirca, L. Pozzetti, F. Maffei, F. Vigagni, P. Hrelia, G. Cantelli-Forti, Genetic and non-genetic biomarkers related to carcinogenesis in evaluating toxicological risk from Fenarimol, Mutat. Res. 368 (1996) 27-39.

[9] C. Di Ilio, P. Sacchetta, V. Iannarelli, A. Aceto, Binding of pesticides to alpha, mu and pi class glutathione transferase, Toxicol. Lett. 76 (1995) 173-177.

[10] S.A. Shahin, K.H. el-Amoodi, Induction of numerical chromosomal aberrations during DNA synthesis using the fungicides nimrod and rubigan-4 in root tips of Vicia faba L., Mutat. Res. 261 (1991) 169-176.

[11] S. Grilli, G. Ancora, P. Rani, A.M. Valenti, M. Mazzullo, A. Colacci, In vivo unwinding fluorimetric assay as evidence of the damage induced by fenarimol and DNOC in rat liver DNA, J. Toxicol. Environ. Health 34 (1991) 485-494.

[12] R.D. Combes, Genotoxicity testing: recent advances and future trends, Chem. Ind. 24 (1992) 950-954.

[13] D. Fairbairn, D. Meyers, K. O'Neill, Detection of DNA damaging agents in environmental water samples, Bull. Environ. Contam. Toxicol. 52 (1994) 687-690.
[14] L. Calderón-Garcidueñas, N. Osnaya, A. Rodríguez-Alcaraz, A. Villarreal-Calderón, DNA damage in nasal respiratory epithelium from children exposed to urban pollution, Environ. Mol. Mutagen. 30 (1997) 11-20.

[15] C.L. Mitchelmore, J.K. Chipman, DNA strand breakage in aquatic organisms and the potential value of the Comet assay in environmental monitoring, Mutat. Res. 399 (1998) 135147.

[16] J.T. Wilson, P.L. Pascoe, J.M. Perry, D.R. Dixon, Evaluation of the Comet assay as a method for the detection of DNA damage in the cells of a marine invertebrate, Mytilus edulis L. (Mollusca: Pelecypoda), Mutat. Res. 399 (1998) 87-95.

[17] S. Cotelle, J.F. Ferard, Comet assay in genetic ecotoxicology: a review, Environ. Mol. Mutagen. 34 (1999) 246-255.

[18] H. Cerda, H. Delincée, H. Haine, H. Rupp, The DNA 'Comet assay' as a rapid screening technique to control irradiated food, Mutat. Res. 375 (1997) 167-181.

[19] G. Koppen, L. Verschaeve, The alkaline Comet test on plant cells: a new genotoxicity test for DNA breaks in Vicia faba root cells, Mutat. Res. 360 (1996) 193-200.

[20] G. Koppen, K.J. Angelis, Repair of X-ray induced DNA damage measured by the Comet assay in roots of Vicia faba, Environ. Mol. Mutagen. 32 (1998) 281-285.

[21] G. Koppen, L.M. Toncelli, L. Triest, L. Verschave, The Comet assay: a tool to study alteration of DNA integrity in developing plant leaves, Mech. Ageing Dev. 110 (1999) 13-24.

[22] K.J. Angelis, M. McGuffie, M. Menke, I. Schubert, Adaptation to alkylation damage in DNA measured by the Comet assay, Environ. Mol. Mutagen. 36 (2000) 146-150.

[23] T. Gichner, M. Menke, D.A. Stavreva, I. Schubert, Maleic hydrazide induces genotoxic effects but no DNA damage detectable by the Comet assay in tobacco and field beans, Mutagenesis 15 (2000a) 385-389.

[24] M. Menke, A. Meister, I. Schubert, $N$-Methyl- $N$-nitrosoureainduced DNA damage detected by the Comet assay in Vicia faba nuclei during all interphase stages is not restricted to chromatid aberration hot spots, Mutagenesis 15 (2000) 503506.

[25] M.H. Navarrete, P. Carrera, M. de Miguel, C. de la Torre, A fast Comet assay variant for solid tissue cells. The assessment of DNA damage in higher plants, Mutat. Res. 389 (1997) 271-277.

[26] T. Gichner, M.J. Plewa, Induction of somatic DNA damage as measured by single cell gel electrophoresis and point mutation in leaves of tobacco plants, Mutat. Res. 401 (1998) 143-152.

[27] T. Gichner, O. Ptacek, D.A. Stavreva, E.D. Wagner, M.J. Plewa, A comparison of DNA repair using the Comet assay in tobacco seedlings after exposure to alkylating agents or ionizing radiation, Mutat. Res. 470 (2000) 1-9.

[28] P. Poli, A. Buschini, A. Ficarelli, F.M. Restivo, T.M.A.D. Zucchi, C. Rossi, The Comet assay applied to microorganisms and plants: methods and problems, Neoplasma 46S (1999a) 74-75.

[29] P. Poli, A. Buschini, F.M. Restivo, A. Ficarelli, F. Cassoni, I. Ferrero, C. Rossi, Comet assay application in environmental monitoring: DNA damage in human leukocytes and plant cells in comparison with bacterial and yeast tests, Mutagenesis 14 (1999b) 547-555. 
[30] F.M. Restivo, M.C. Iaccone, A. Buschini, C. Rossi, P. Poli, Indoor and outdoor genotoxic load detected by the Comet assay in leaves of Nicotiana tabacum, cultivars Bel B and Bel W3, Mutagenesis 17 (2002) 127-134.

[31] N.P. Singh, M.T. McCoy, R.R. Tice, E.L. Schneider, A simple technique for quantitation of low levels of DNA damage in individual cells, Exp. Cell Res. 175 (1988) 184-191.

[32] D.W. Fairbairn, P.L. Olive, K.L. O'Neill, The Comet assay: a comprehensive review, Mutat. Res. 339 (1995) 37-59.

[33] H. Kobayashi, C. Sugiyama, Y. Morikawa, M. Hayashi, T. Sofuni, A comparison between manual microscopic analysis and computerized image analysis in the single cell gel electrophoresis assay, MMS Commun. 3 (1995) 103-115.

[34] L.F. Povirk, H.J. Finley Austin, Genotoxicity of bleomycin, Mutat. Res. 257 (1991) 127-143.

[35] L.F. Povirk, DNA damage and mutagenesis by radiomimetic DNA cleaving agents: bleomycin, neocarzinostatin and other enediynes, Mutat. Res. 355 (1996) 71-89.

[36] O. Merk, G. Speit, Detection of crosslinks with the Comet assay in relationship to genotoxicity and cytotoxicity, Environ. Mol. Mutagen. 33 (1999) 167-172.

[37] R.R. Tice, E. Agurell, D. Anderson, B. Burlinson, A. Hartmann, H. Kobayashi, Y. Miyamae, E. Rojas, J.-C. Ryu,
Y.F. Sasaki, Single cell gel/Comet assay: guideline for in vitro and in vivo genetic toxicology testing, Environ. Mol. Mutagen. 35 (2000) 206-221.

[38] S. Meintieres, F. Nesslany, M. Pallardy, D. Marzin, Detection of ghost cells in the standard alkaline Comet assay is not a good measure of apoptosis, Environ. Mol. Mutagen. 41 (2003) 260-269.

[39] D. Anderson, T.-W. Yu, B.J. Phillips, P. Schmezer, The effect of various antioxidants and other modifying agents on oxygenradical-generated DNA damage in human lymphocytes in the COMET assay, Mutat. Res. 307 (1994) 261-271.

[40] P.R. Heaton, R. Ransley, C.J. Charlton, S.J. Mann, J. Stevenson, B.H.E. Smith, J.M. Rawlings, E.J. Harper, Application of single-cell gel electrophoresis (Comet) assay for assessing levels of DNA damage in canine and feline leukocytes, J. Nutr. 132 (2002) 1598S-1603S.

[41] A. Buschini, C. Alessandrini, A. Martino, L. Pasini, V. Rizzoli, C. Carlo-Stella, P. Poli, C. Rossi, Bleomycin genotoxicity and amifostine (WR-2721) cell protection in normal leukocytes vs. K562 tumoral cells, Biochem. Pharmacol. 63 (2002) 967-975.

[42] USA National Research Council, Pesticides in Food, National Academy of Science Press, Washington, DC, 1987. 